\title{
Chapter 7 \\ The Ethnic Question: Census Politics \\ in Great Britain
}

\author{
Debra Thompson
}

\subsection{Introduction}

In her analysis of a global data set compiled by the United Nations Statistical Division to survey the approaches to ethnic enumeration, Ann Morning (2008) finds that of the 141 countries under study, $63 \%$ incorporate some form of ethnic enumeration though question and answer schema vary along dimensions that suggest diverse conceptualisations of race/ethnicity/indigeneity/nationality. Given the substantial number of countries that enumerate identity, it is no surprise that the academic scholarship envisions the census in a variety of ways. One of the first analytical treatments of the census appeared in Benedict Anderson's seminal work on nationalism, Imagined Communities. The census, Anderson argues, is one of the three institutions (alongside maps and museums) that states use to create a common imagination for its subjects (Anderson 1991: 163-164). James Scott's understanding of the census is similar - it is part of the state's ongoing 'project of legibility' in which instruments of statecraft such as the census, the map, surnames, the centralisation of traffic patterns, the creation of official languages, and even scientific forestry are used to create both a geographical terrain and population with standardised characteristics that will be most efficiently monitored, counted, assessed and managed (Scott 1998: 81-82). Statistics are indeed the science of the state, as Foucault points out in his essay on governmentality. The production of statistics leads to the 'emergence of population,' an outcome that relies on the will of the population to itself be managed (Foucault 1991).

However, the most common interpretation by policymakers and political elites is to think of the census as an instrument of governance rather than a potentially insidious instrument of statecraft. The data produced by the census are a crucial source

\footnotetext{
D. Thompson $(\bowtie)$

Department of African American Studies, Northwestern University, Evanston, IL, USA

e-mail: debra.thompson@northwestern.edu
} 
of information that allows governments to make policies; the census is the neutral tool of demographers that provides a wealth of statistical data for various government sectors, like health and education (Simon 2004; Potvin 2005; Aspinall 2000, 2003). The three most dominant explanations claim census politics are driven by demography, civil rights legislation, social mobilisation, or some combination thereof. Official government documents are most likely to give causal weight to demography and the need to make the census institutionally consistent with civil rights legislation. ${ }^{1}$ In the United States, explanations of census politics also emphasise the causal role of social mobilisation. These accounts have been particularly dominant in explaining the adoption of a 'mark one or more' approach on the 2000 census, which scholars claim can be attributed to the actions of a very vocal mixedrace social movement that pushed Congress for the change to its classification standards (Nobles 2000; Aspinall 2003; Williams 2006; DaCosta 2007).

These interpretations of both the nature of the census and drivers of census politics seem insufficient. Though the data on ethnicity and race produced from censuses are indeed critical for the state to monitor the effectiveness of, for example, anti-discrimination policies, this is one among many other possible employments of the census as an instrument of government(ality). Kertzer and Arel (2002) argue that the census does not simply reflect objective social reality, but rather plays a constitutive role in the construction of that reality. ${ }^{2}$ In this instrumentality, the very idea of race - however constructed, constituted, or fabricated - is animated through the forum of the census and further solidified in law and policy. The census is a contributing (though not a monopolising creational) factor in the proliferation of racial taxonomies. In turn, censuses help to constitute racial discourse, which itself helps to shape and explain policy outcomes (Nobles 2002: 43). Using the Americanled academic literature on the social construction of race, the census can also be conceptualised as a racial project ${ }^{3}$ (Omi and Winant 1994): governmental conceptions of the meaning of race are developed (Where do the dividing lines between

\footnotetext{
${ }^{1}$ For example, Canada, the US and the UK all have legislation in place that relies on statistical data produced from the census in order to monitor the extent of racial discrimination in employment, housing, and other areas of social life. In the United States, the relevant legislation is the Civil Rights Act (1964) and the Voting Rights Act (1965), compared with Great Britain's Race Relations Act (1976; 2000) and Canada's Employment Equity Act (1986; 1995). All three countries also use census data to fund a wide array of social programs.

${ }^{2}$ On the census as a causal factor that affects national identity, see Miller (2007).

${ }^{3}$ Omi and Winant (1994) contend that a racial project is 'simultaneously an interpretation, representation or explanation of racial dynamics, and an effort to reorganize and redistribute resources along particular racial lines' (1994: 56; emphasis in original). Racial projects link together social structures and experiences that are racially organised with the meaning of race in a particular discursive practice. For example, the politically organised racial projects of the New Right claim to hold colour-blind views but covertly manipulate racial threats and fears in order to achieve political power (1994: 58). Another example is nationalist projects, which stress the extent to which racial identity is incompatible with the production of a homogenous nation and demand the separation of the two (1994: 59). These exemplify macro-level, sometimes state-driven projects in which very particular discursive meanings of race are connected with ideas about or attempts to organise institutions, policies and other social structures in accordance with the discursive meanings.
} 
races lie? Who should count as white/non-white? What racial labels are appropriate for which groups?) and connected with a means of organising society (Are racial classifications discrete or multiple? Which racial groups should have access to government programming?). The census categories themselves are less important than the fact of social differentiation (Brown 2009: 15) and the role of the state in promoting and reifying it.

The argument that approaches to racial enumeration employed in national censuses are driven by singular causes such as demography, civil rights legislation or social mobilisation also misses important nuances of the dynamics of census politics and are unlikely to hold true across time and space. In their analysis of racial enumeration throughout the world, Rallu et al. (2004) identify four main government approaches to racial enumeration. The first, counting to dominate, characterises the colonial situation and other cases such as the Soviet Union and early twentieth century North America, whereby censuses were politically important tools for collectively identifying racialized others. Second, not counting in the name of national integration occurs when race or ethnicity is rejected either in the name of national integration, as is presently the case in many African countries, or in the name of the republican principle of national unity as occurs in Western Europe. The third approach, counting or not counting in the name of multiculturalism, refers to Latin America's tendency to valorise racial mixing through the distinct practices of either not counting by race, which emphasises racial hybridity beyond counting, or to count by race, which promotes harmonious race relations by measuring the country's degree of whitening. Finally, counting to justify positive action invokes the pluralist models of Canada, the United States and Great Britain, all of which view racial enumeration as a tool in the fight against discrimination (Rallu et al. 2004: 534-536).

This chapter explores the political development of the ethnic question ${ }^{4}$ on the British census. It seeks to complicate these causal accounts, which have a tendency to over-simplify the complex political processes involved in the politics of racial

\footnotetext{
${ }^{4}$ This chapter's use of the terminology of 'race' versus 'ethnicity' is a tricky business. It will most often refer to the question on the census as an "ethnic question," because this is the terminology used on the census, in archival records, and by those in Britain. However, I am hesitant to use the language of ethnicity in my analysis. Like race, ethnicity is a social signifier of identity, but it is also fundamentally different. Ethnicity, which can overlap and intersect with race, often describes a collectivity with common ancestry, a shared past, culture and language, and a sense of peoplehood or community (Cornell and Hartmann 2007: 16-20). The importance of race or ethnicity in a given society is context-specific. However, the origins of race are in assignment and categorization, and while ethnicity can have similar beginnings it is more often associated with the assertions of group members (Cornell and Hartmann 2007: 28). Race is not simply about skin colour and morphological characteristics, but rather should be understood as the signifier of a complex set of power relations: 'power is almost invariably an aspect of race; it may or may not be an aspect of ethnicity' (Cornell and Hartmann 2007: 31). In conducting this research, it seems to me that the language of ethnicity by elites, policy-makers and academics is often used to disguise these power relations and I am wary of furthering this problematic tendency. My use of race is also not a dramatic departure from what the Office of Population Censuses and Surveys (OPCS) itself has noted: 'the census ethnic categories are essentially racial' (OPCS 1996: 40, emphasis added).
} 
enumeration, by devoting particular attention to the cumulative and compounded relationships among ideas, institutions and interests that permeate census politics in Great Britain. In doing so, I make two general arguments. First, the British state has changed its approach to counting race over time. Using Rallu et al.'s (2004) typology, I argue that the British state has transitioned from not counting in the name of multiculturalism in the 1981 census to counting to justify positive action after the introduction of the ethnic question in 1991 and finally, counting in the name of multiculturalism with the modifications to the question in 2001. Secondly, my analysis of the political development of the ethnic question on the British census between 1981 and 2001 will demonstrate that censuses are not simply reflective of demographic reality or a consequence of social mobilisation or the state's initiative to maintain consistency with its civil rights legislation, but rather are inherently connected to debates over the nature of citizenship and belonging in a given country. These debates are partially informed by ideas about race, colour, ethnicity and difference, which are mitigated through the institutions of the state and are given administrative life and scientific legitimacy through the forum of the census.

\subsection{Not Counting in the Name of Multiculturalism: Census Politics in the 1970s and 1980s}

The tradition of censuses ${ }^{5}$ of the population in Great Britain dates back over 200 years; however, census question on ethnic identity only appeared on the decennial census in $1991 .^{6}$ This inclusion effectively aligns Great Britain more closely immigration-based countries such as the United States, Canada, Australia and New Zealand than with other Western European states, which do not have census questions on race or ethnicity (Coleman and Salt 1996: 17-23).

Though Blacks and Asians have a long history in Britain (Fryer 1984; Ramdin 1999), the majority of the non-white population derives from the arrival of immigrants from the Commonwealth in the post-World War II era, when debates over

\footnotetext{
${ }^{5}$ Strictly speaking, there are currently three censuses in the UK - England and Wales, Scotland and Northern Ireland. Beginning in 2001 final decision-making power on the questions to be included in the census was devolved to the legislatures of Scotland and Northern Ireland. Although the census content of these three endeavours is closely related, the specific wording of the question on ethnicity and even the timing of its introduction have been known to vary; for example, a question on ethnicity appeared for the first time in Northern Ireland in 2001, 10 years after its introduction in other parts of Britain. This chapter focuses on the census in England and Wales because of the institutional prominence of OPCS and its path-breaking decisions on whether or not (and the extent to which) a question on ethnicity should be included.

${ }^{6}$ Between 1841 and 1961 (excluding 1941, in which Great Britain did not conduct a decennial census) the census included a question on nationality. In 1841 this question pertained only to persons born in Scotland or Ireland, while the years between 1851 and 1891 contained a question as to whether or not the respondent was a British subject. A complete list of Census topics from 1801 to 2001 can be found at http://www.statistics.gov.uk/census2001/pdfs/topics_1801_2001.pdf.
} 
immigration became increasingly racialized in spite of the fact that the majority of immigrants to Britain during this time came from European countries and Ireland (Solomos 2003). The history of British immigration control has been documented more extensively elsewhere ${ }^{7}$; for our purposes, however, the political responses to increased non-white immigration are of interest. Linking the seemingly contradictory elements of state imposition of racially specific immigration controls and measures to prevent racial discrimination towards the non-white population already residing in Britain, the Race Relations Acts of 1965 and 1968 sought to end discrimination based on race. As Labour MP Roy Hattersley famously stated, 'Integration without control is impossible, but control without integration is indefensible. ${ }^{8}$ The concept of integration was wrought with an air of prevention; at the time it was believed that without political institutions to address the social problems of immigrants, Britain would soon be facing the prospect of US-style racial tension and violence (Solomos 2003: 81). The tasks of the Race Relations Acts of 1965 and 1968 were therefore to set up special bodies to deal with problems faced by immigrants in relation to discrimination, social welfare and integration and to educate the population as a whole about race relations in an attempt to minimise the potential for racial conflict.

Though the census was the most obvious vehicle to gather information on both the extent of racial discrimination and the effectiveness of the Race Relations Acts of the 1960s, it was not considered feasible to ask a question on race or ethnic identity in preparation for the 1971 census. The assertion of Dale and Holdsworth (1997) that the General Register Office (the predecessor of the Office of Population Censuses and Surveys) was adamant that such a question be neither asked nor answered is not entirely correct. The decision to include a question on parents' country of birth - rather than the previously asked question about the respondents' 'country of origin' or a direct question on race or ethnicity - reveals the internal politicking at work within the state apparatus. Bureaucrats discussed the possibility of including a question on ethnic origin in the census as early as $1966 .{ }^{9}$ When plans for the 1971 census took more definite shape in 1967, the bureaucrats at the Ministry of Health suggested there should be a question on ethnic origin, but the Home Office could not initially agree to support this proposal because of the "considerable political implications' of asking the question, even in the context of a test survey. However, the need for racial data was acknowledged by senior Home Office bureaucrat Jack Howard-Drake, who wrote in a memo that his initial concern surrounded 'the impossibility of defining immigrant or colour in precise terms,' but that he was

\footnotetext{
${ }^{7}$ See, for example, Paul (1997); Spencer (1997); Joppke (1999); see also Hansen (1999) for a different view. Though the British government did not restrict immigration by legislative action until the Commonwealth Immigrants Act of 1962, a study by Carter et al. (1987) concluded that between 1948 and 1962 the state was involved in a complex political and ideological racialisation of British immigration policy, in which covert and sometimes illegal administrative measures were implemented by both Labour and Conservative Governments to discourage Black immigration.
}

${ }^{8}$ Hansard, House of Commons, Vol. 709, col. 378-85.

${ }^{9}$ PRO HO 376/175, Letter by J.T.A. Howard-Drake to Miss Hornsby, 14 November 1966. 
'now not so sure that this view is correct,' noting that '[with] the emergence of the second generation it will become increasingly important for us to have as much statistical information as we can about the coloured minority in the United Kingdom'.${ }^{10}$ In early 1968 the matter was referred to the Statistical Policy Committee for Ministers to decide; therein, the majority of the Committee were clearly in favour of collecting information about racial origin and decided to make the suggestion at the upcoming Home Affairs Committee meeting. ${ }^{11}$ At this meeting the Minister of Health proposed that a question on ethnic origin be included on the census, but the Secretary of State recorded his concern about the 'political difficulties' that would result, ${ }^{12}$ and the decision to include a question on 'parents' country of origin' rather than a direct question on race was decided at the Ministerial level ${ }^{13}$ though Cabinet acknowledged that using this proxy would not provide accurate information on ethnic origin. ${ }^{14}$

This initial call for a direct question on ethnicity therefore originated with bureaucrats in line departments and central agencies, who had discussed the issue internally for 2 years before it was proposed to Ministers. At the ministerial level the proposal was met with hesitance and caution, as political considerations (that had indeed been acknowledged by bureaucrats) played a much larger role in the decisionmaking process. These 'considerable political implications' were many: first, British bureaucrats and Ministers alike felt that it was impossible to define race or colour in the precise terms required for a statistical exercise such as the census. Second, there was a clear concern that asking a direct question on race or colour would be perceived as offensive to both 'coloured' and white respondents. The proposal to instead ask the country of origin of the respondent's parents was more familiar, and thus less controversial, since the 1961 census asked for country of birth with the intention of identifying immigrants to the United Kingdom. The 1971 question, designed to identify the children of these immigrants, was not the extreme break from tradition that a direct question on ethnicity represented. Third, the government could not ignore the political implications that arose from its own policies. The Race Relations Act of 1968 was on the table during this decision-making process and given the Labour government's 'acknowledged as accepted policy to

\footnotetext{
${ }^{10}$ PRO HO 376/175, Minute by J.T.A Howard-Drake 17 November 1967.

${ }^{11}$ PRO HO 376/175, letter from J.T.A Howard-Drake to Mr. Weiler, 19 January 1968. There were also substantial discussions at the meetings of the Select Committee on Race Relations and Immigration in 1968 and 1969, but these took place after the decision to not include a direct question on ethnicity had already been made (PRO HO 376/123).

${ }^{12}$ PRO HO 376/175, Note on the Home Affairs Committee meeting, n.a., 6 February 1968.

${ }^{13}$ PRO HO 376/123, Memorandum on the Collection of Racial Statistics, Cabinet Committee on Immigration and Community Relations, 19 March 1969.

${ }^{14}$ PRO HO 376/124, Cabinet document dated 6 February 1968. The original wording of the question on parents' country of origin stated: 'Was your father/mother of African, Asian or West Indian origin? If "yes" state the country (for example, Pakistan, Nigeria, Jamaica, etc.).' This was later changed to a more generic question about parents' country of origin because this original version was too explicit in its focus on the non-white population (PRO HO 376/175, Paper to Statistical Policy Committee, January 1968).
} 
promote the integration of the immigrant population,' a memo to the Prime Minister on the issue stated that it was 'undeniably important that the Departments concerned should have particulars of [the immigrant population's] numbers, whereabouts, employment, housing circumstances, education and so forth' ${ }^{15}$ The memo also notes that a failure to collect this information, or, as it was put at the time, to 'take the opportunity of obtaining it,' would open the government to criticism about the seriousness of their commitment to ending racial discrimination in Great Britain. ${ }^{16}$

Finally, and likely most relevant, were the implications of the politics of numbers, which became a salient issue in Britain for a variety of reasons. In a time of restrictionist immigration policy, anti-immigration agitators laid claim that the actual size of the Black population in Britain was considerably larger than official estimates (Bulmer 1986: 472). For example, in 1964 the Conservative MP Peter Griffiths ran in the general election in the constituency of Smethwick under the infamous anti-immigration slogan, 'If you want a nigger for a neighbour, vote Liberal or Labour' - and won. Four years later, coinciding with the decision to avoid a direct question on race in the 1971 census, Enoch Powell made his famous 'Rivers of Blood' speech to the West Midlands Conservative Political Centre in Birmingham. Any statistics concerning the actual size of the non-white population Britain could serve multiple politically instrumental purposes: on the one hand, the forthcoming census data could be used to, as bureaucrats hoped, establish the true facts and 'disprove wild estimates of the future coloured population' ${ }^{17}$; on the other hand, Conservatives sought the same facts to call for more restrictive immigration policies. The seminal study of race in Britain of this time, Colour and Citizenship, noted that fears of being 'swamped' by the incoming 'flood' of immigrants was a key element to the formation of racist attitudes and that these fears were largely derived from exaggerated notions about the size of the coloured population, which, the study notes, were compounded by the absence of reliable statistics on the subject (Rose et al. 1969: 551-605). The connection between immigration and race relations was as much numerical as political - would the natural increase of the second and third generations of non-white Britons make immigration restrictions less salient, or would it give further reason to restrict the flow?

These political considerations inhibited the government's willingness to directly enumerate race; as such, the 1971 census collected information on both the respondent's country of birth (as in the 1961 census) and his or her parent's country of birth in order to gauge the approximate size of the racial population. It was acknowledged at the time - and indeed, throughout the policy-making process - that this method would be inaccurate for enumerating those white Britons who happened to be born in colonies overseas, pockets of the historic (and indigenous) Black British population, in, for example, Cardiff and Liverpool and people of mixed-race. There were also concerns regarding the extent to which mixed-race people should be

\footnotetext{
${ }^{15}$ PRO PREM 13/2703, Memo to Prime Minister, subsection Country of origin of the respondent's parents, 5 February 1968.

${ }^{16}$ Ibid.

${ }^{17}$ PRO HO 376/175, memo by Miss M. Hornsby, 11 November 1966.
} 
'counted' as part of the New Commonwealth immigrant population. ${ }^{18}$ Generated indirectly using country of birth, parents' country of birth, nationality and surnames, the subsequent census data was flawed and proved inaccurate (Sillitoe and White 1992: 142; Ballard 1996: 10), but nevertheless estimated that $36.5 \%$ of the nonwhite British population was born in the UK (OPCS 1975).

Thus, in spite of over a decade of legislation on racial integration in the UK, the state did not address the need for explicit racial census data until the mid-1970s. Though the proposal was still controversial at the time, there was a growing number of public bodies that advocated for the collection of racial statistics, including the Race Relations Board (1975: 9), the Community Relations Commission (1975: 10), and the Parliamentary Select Committee on Race Relations and Immigration (HM Government 1975: 20-22). ${ }^{19}$ A series of field trials between 1975 and 1979 were instigated by the Office of Population Censuses and Surveys (OPCS) ${ }^{20}$ in order to develop a direct question on race/ethnicity that would be both acceptable to the public and would generate more reliable and accurate than the indirect question in 1971. In general, however, there were two main difficulties recorded by OPCS bureaucrat Ken Sillitoe (1978a, b, c). First, the classification of mixed-race respondents presented a problem to the question designers, with twenty percent having provided 'ambiguous' answers and fifteen percent providing 'no answer' during field trials in 1975, likely because respondents were unclear which box to check (Sillitoe 1978a: 15). The second difficulty was that West Indians were suspicious of the motives behind the data collection; response rates were generally low and this group was among the most likely to object to the ethnicity question on principle. However, Sillitoe notes that the hostility could be avoided if they were able to design some form of category 'to record that although of non-UK descent he is nevertheless a U.K. citizen...because asking about ethnic origins only [...] can be taken to imply that anyone who is not of U.K. origin continues to be in some sense different, or alien to our society, no matter how long he or his forebears have been in Britain' (Sillitoe 1978a: 46).

\footnotetext{
${ }^{18}$ PRO HO 332/58, Report of the Working Party on Departmental Statistics for Commonwealth Immigrants, April 1970. On this issue, the report recommends: 'We do not think that it is possible to recommend any hard and fast rule be followed. But it seems likely that we are moving to a stage when it will often at least be necessary to make available figures for children with one parent born in a new Commonwealth country at the same time as figures for those with both parents so born. In some instances however knowledge of the local situation might indicate whether children born to parents whose country of birth differs could properly be excluded from the "immigrant group".' It was eventually decided to include mixed-race persons as part of the New Commonwealth population; a 'statistical difficulty' resolved in this manner "partly due to the political climate and to Mr. [Enoch] Powell's influence on the terms of the discussion" (PRO RG 26/436).

${ }^{19}$ However, as Erik Bleich points out, the continued tension surrounding the collection of racial data was epitomized by the Home Office's White Paper on race relations, which stated that 'the Government considers that a vital ingredient of equal opportunities policy is a regular system of monitoring,' but failed to recommend the collection of the racial data that would support these activities (2006: 228).

${ }^{20}$ The OPCS merged with the Central Statistical Office in 1996 and is now called the Office for National Statistics.
} 
The testing of an ethnic question did not guarantee its implementation on the 1981 census. The 1978 report of the Select Committee on Race Relations and Immigration recommended including an ethnic question and Ministers with responsibilities for social services felt that better information about ethnic minorities was required. However, some central agencies, including the Lord President of the (Privy) Council, Michael Foot, felt that the adoption of such a question would be 'ill-advised' given the recent focusing of the public's attention on immigration issues in the pre-election period. ${ }^{21}$ Specifically, the Cabinet felt that 'the category "white" in particular would be open to sensational and damaging treatment in the popular Press'. ${ }^{22}$ However, the political considerations of the previous decade remained salient; Cabinet concluded that a reintroduction of the 1971 question on parents' country of origin would not only be ineffective, but would also be interpreted as a sign of weakness, showing a lack of resolve to tackle the problems of racial disadvantage. The final decision, summed up by Prime Minister James Callaghan, recognised the need for the racial data that could be provided by a direct question on the census, but noted that Cabinet 'rejected the form of the question proposed for the census test, in particular the inclusion of the category "white". ${ }^{23}$

OPCS heeded the Cabinet order to find alternative system of classification couched exclusively in ethnic terms and in the Census Test in the London borough of Haringey in 1979 the ethnic designations 'English, Welsh, Scottish or Irish' were used as well as a further category, 'Other European,' alongside the 'non-white' ethno-national-geographical categories of 'West Indian or Guyanese,' 'African,' 'Indian,' 'Pakistani,' 'Bangladeshi,' 'Arab,' 'Chinese,' and 'Any other racial or ethnic group, or if of mixed racial or ethnic descent'. However, the results of this test were greatly affected by a campaign by local organisations and the media which urged people not to answer the question on race or ethnicity; 25,000 pamphlets were purportedly distributed to residents, linking these questions to the proposed nationality laws that 'would make nationality dependent on your parents' nationality, not where you were born [...] If we say now who is and who is not of British descent, we may one day asked to 'go home' if we were born here or not' (cited in OPCS 1990: 9). In this pre-election climate of 1979, the connection between race and immigration was explicit: the politics of numbers was (in)famously reinforced by the future Prime Minister Margaret Thatcher, who when asked about Tory policy on immigration in a January 1979 television interview for Granada World in Action stated:

Well, now, look, let us try and start with a few figures as far as we know them...if we went on as we are then by the end of the century there would be four million people of the new Commonwealth or Pakistan here. Now, that is an awful lot and I think it means that people are really rather afraid that this country might be rather swamped by people with a different culture and, you know, the British character has done so much for democracy for law and

\footnotetext{
${ }^{21}$ PRO CAB 128/63/14, Conclusions of Cabinet Meeting, 13 April 1978.

${ }^{22}$ Ibid.

${ }^{23}$ Ibid.
} 
done so much throughout the world that if there is any fear that it might be swamped people are going to react and be rather hostile to those coming in. ${ }^{24}$

The concern of racial minorities in Haringey was clearly related to these proposed immigration controls and Nationality Act, the latter of which was passed by Thatcher's government in 1981 and was criticized for reinforcing discriminatory immigration policies: 'Indeed, the category of British Overseas Citizen effectively deprived British citizens of (mostly) Asian origin of the right to live in Britain' (Solomos 2003: 65). Two years before this Act saw the light of day, campaigners believed that the reformed nationality law would jeopardise the status of racial minorities in Britain. The local campaign against the 1979 census test was therefore based on false but understandable concerns. Regardless, the number of people who objected in principle to the questions on ethnicity rose dramatically, with only $54 \%$ of households returning their census test forms and as many as $32 \%$ of both the West Indian and Asian respondents expressing views that they thought the inclusion of such a question was wrong. Even greater objections were expressed in regards to the parents' country of birth question (OPCS 1980). After consultations with ethnic organisations following the Haringey affair, the government decided in November 1979 to not include a question on ethnicity in the 1981 census.

Archival research reveals that Haringey was indeed an important factor that led to the exclusion of the ethnic question; however, other mitigating circumstances played important and often overlooked roles in the government decision-making process. The position that a potentially offensive ethnic question would jeopardise the entire census project was taken by the Registrar General (the head of OPCS); however, it is likely that the same line departments responsible for social services that had argued for racial data since the 1960s continued to do so. In post-Haringey consultations with the ethnic minority organisations and the public, opinion was split. Some powerful organisations, such as university departments, census users, and the Commission for Racial Equality, argued that an ethnic question was necessary to monitor and combat racial disadvantage and that the incident in Haringey was largely caused by inadequate public relations (Commission for Racial Equality 1980). Others, including the British Society for Social Responsibility in Science, the Haringey Community Relations Council and numerous ethnic organisations, vehemently opposed the inclusion of a question for a variety of reasons, ranging from the contention that the collection of racial data indicates that non-whites rather than institutional racism - were the problem ${ }^{25}$ to the 'uncertainty of the Government's intention on the nationality law. ${ }^{.26}$ In the end, the decision to present

\footnotetext{
${ }^{24} \mathrm{http}: / / \mathrm{www}$.margaretthatcher.org/speeches/displaydocument.asp?docid=103485, site viewed 6 June 2009. Note that the BBC transcript is slightly different that this, the Granada transcript, recording that Thatcher commented that people are afraid of being swamped by people of a different culture (emphasis added).

${ }^{25}$ PRO HO 376/223, Press Release - British Society for Social Responsibility in Science, 17 October 1979.

${ }^{26}$ PRO HO 376/223, Haringey Community Relations Council - Response to 1981 Census Test, July 1979.
} 
the government's conclusion as a technical one was partially a matter of political spin. An internal memo to Home Secretary William Whitelaw and Minister of State Tim Raison noted that the use of the 'technical' justification was the lesser of all evils:

The least unsatisfactory course would seem to be to try to present the decision as essentially a technical one; namely, that the Haringey test has shown that the Census is not a way of getting this information and that the Government will employ other and more acceptable techniques. It will be particularly important, therefore, that any announcement of the decision should be framed in as positive a way as possible, both to emphasise the Government's continuing commitment to obtaining information designed to be used for the benefit of the ethnic minority communities and to indicate that positive steps are being taken to find alternative sources of data. ${ }^{27}$

Again, the government was aware that the exclusion of the ethnic question from the census would leave it open to criticism about its commitment to race relations. Accepting the Registrar General's concern about the ethnic question's potentially damaging effect to the census project as a whole was a convenient way to quash the initiative while minimising the damage to the new government's credibility in the politics of race relations. Moreover, this justification also permitted the government to mask the true weight that organised opposition had in determining the outcome of the Haringey test and the subsequent policy decision to drop the question, a revelation which government officials believed 'could be seriously damaging to race relations' ${ }^{28}$ It is also likely that the mobilising power and impact of ethnic organisations were deeply troubling to government officials - it was therefore necessary to belay any public insinuations that local organisations could so deeply sway the course of politics in Britain.

Another mitigating factor beyond the Haringey test that led to the exclusion of the ethnic question was the role of political climate and ideology. If Haringey had never happened, would the newly instated Conservative government have approved a direct question on race for the 1981 census? The evidence suggests that it is not likely. In a letter from Patrick Jenkin, the Secretary of State for Health and Social Security, to Home Secretary William Whitelaw, Jenkin conveyed that in a meeting with Prime Minister Margaret Thatcher she suggested that much of the information gained from the census was unnecessary because it duplicated data available elsewhere. In a testament to the principles of neo-liberal thought, Thatcher was 'very concerned about the intrusion into the private affairs of individuals and feels strongly that Government will lay itself open to justifiable criticism unless it can be shown that these questions are really necessary for policy analysis and decisions'. ${ }^{29}$ Indeed, upon further inspection Thatcher found many of the questions (i.e., whether

\footnotetext{
${ }^{27}$ PRO HO 376/223, Memo from G.I. de Deney to Raison (Minister of State) and Whitelaw (Secretary of State), 2 November 1979.

${ }^{28} I d$.

${ }^{29}$ PRO 376/223, Letter from Patrick Jenkin, Secretary of State for Social Services, to William Whitelaw, Secretary of State for Home Department, 13 December 1979.
} 
working, retired, housewife, etc.) to be 'completely unnecessary'.30 The state's incursion into the private lives of individuals was a compelling neoconservative concern, complemented well in this circumstance by another tenet of the Conservative platform - cost-cutting. The introductory speech on the 1980 Census Order in the House of Lords ended with the proclamation that the census budget of $£ 44$ million was a $17.5 \%$ decrease in the cost projected by the previous Labour administration's White Paper. ${ }^{31}$ To be clear, the decision to drop the ethnic question from the Census had been made in early November 1979, over a month before Thatcher culled other census questions from the final product. However, as noted by government officials at the time, '[Thatcher's] concern to avoid complexity and unnecessary intervention into privacy seems to be to have been likely to lead her to challenge the ethnic question on these grounds had the decision not already been taken to abandon them. ${ }^{32}$ Haringey or not, the proposed ethnic question would not likely have resurfaced until the 1991 census, when its implementation was unavoidable.

In sum, a variety of ideational, institutional and interest-based factors combined to shape the approach to racial enumeration used by Britain during the 1970s and 1980s, which can best be described as not counting in the name of multiculturalism. According to Rallu et al.'s (2004) typology, this is a circumstance in which 'racial mixing is acknowledged in political and ideological views as a positive value' and therefore the countries do not enumerate according to race or colour. The thrust of this approach lies in the tendency to valorise racial mixing by not counting race, which emphasises racial hybridity beyond the necessity of counting, contrasted with those countries that count by race in the name of multiculturalism, which promotes harmonious race relations by measuring the country's degree of whitening. Though the original formulation of this approach refers to the unique cases of Latin America, I contend its very label - not counting in the name of multiculturalism suggests circumstances when the state intentionally does not count by race in spite of a host of characteristics that imply it would or should. Given the empirical evidence presented here, it is possible to identify a number of more specific idiosyncrasies that characterise the gradients of this approach.

First, states that do not enumerate by race in the name of multiculturalism have a legislative, political or symbolic commitment to multiculturalism, however defined. ${ }^{33}$ Second, quite aside from this commitment to multiculturalism, there will also often be legislation that prohibits discriminatory state action and condemns

\footnotetext{
${ }^{30} \mathrm{Ibid}$.

${ }^{31}$ Hansard, House of Lords, vol. 408, 22 April 1980, col. 737.

${ }^{32}$ PRO HO 376/223, Letter from G.I. de Deney to Miss Maurice (Director of Statistics), re: 1981 Census Ethnic Question, 12 December 1979.

${ }^{33}$ Multicultural regimes are defined differently in various national contexts, but ultimately speak to similar principles. For example, paradigms of multiculturalism, racial equality and racial integration are not the same, and yet all employ similar principles of non-assimilation and respect for racial and/or cultural difference, and are enshrined in other political or discursive attempts to create a national community based on these principles.
} 
racial discrimination in housing, employment, and other areas of social life. This legislation, however ineffectively designed or implemented, has the goal of alleviating or eradicating racial disadvantage in social, political and economic life. Third, in spite of both commitments to multiculturalism and legislation that may require racial statistics to be properly implemented or to create a more effective system of monitoring, there is still controversy or general discomfort around the very notion of race. In the upper echelons of government, this controversy or discomfort translates into the general idea that counting by race will negatively affect national and social cohesion. Fourth, the aversion of race and racialism is specific to counting by race and is not necessarily an opposition to colour-consciousness. In other areas of law and policy, colour-consciousness may feature predominately or may appear in other political commitments to racial equality. In short, states do not wholly or explicitly adhere to the republican principle of colour-blindness, and therefore not counting by race in the census is not because the state itself ignores race is all avenues. ${ }^{34}$ And finally, this refusal to count often occurs in spite of calls for the collection of racial data or an acknowledged need for racial statistics from within the state.

\subsection{Counting to Justify Positive Action: The 1991 Census $^{35}$}

The state's approach of not counting in the name of multiculturalism proved unsustainable. The unavoidability of the direct question on race was partially due to the fact that disparate arms of state authority had begun to publically recognise the need for racial data. Vocal support for the question had unwaveringly been provided by the Commission for Racial Equality (CRE 1980) and this call for change was augmented by several prominent governmental bodies. Calls for a direct question on ethnicity were made by the 1981 report of the Home Affairs Committee on Racial Disadvantage and Lord Scarman's 1982 Report on the Brixton riots (Leech 1989: 9), but the most influential call for action was to come from the Sub-Committee on Race Relations and Immigration. The Sub-Committee began its enquiry into whether or not an ethnic or racial question should be asked on the national census in 1982, inviting evidence from a variety of external stakeholders, including Local Authorities, other public bodies such as Health Authorities and ethnic minority organisations. Its members also travelled to Canada and the United States to familiarise themselves with the collection of ethnic and racial data in other countries. In

\footnotetext{
${ }^{34}$ This is the crucial distinction between two approaches to racial enumeration: not counting in the name of multiculturalism and not counting in the name of national integration, the latter of which occurs when race or ethnicity is rejected in the name of national integration, as is presently the case in many African nations, or in the name of the republican principle of national unity as occurs in Western Europe.

${ }^{35}$ See Appendix 7.1.
} 
its parliamentary report issued in May 1983, the multi-party Sub-Committee ${ }^{36}$ publically regretted the decision to not include a question on ethnicity in the 1981 census. The report reviewed the need for information on ethnic groups in order to monitor the effectiveness of anti-discrimination policy and proposed that the OPCS carry out a further series of field tests to develop an improved design of question on race and/or ethnicity for possible inclusion in the 1991 census. The report accepted that the racial terms 'White' and 'Black' would need to be employed and went so far as to suggest a design for the ethnic question. In its reply the following year, the government accepted many of these recommendations in principle, noting that further tests needed to be carried out in order to create a reliable and publically acceptable question for the 1991 census (HM Government 1984). Thus the decision to once again address the issue of race and the census was not exactly coming from within the depths of the state itself, but nor did the driver of change derive from a completely external force, such as interest groups, social mobilisation or an exogenous shock. Though Scarman's inquiry and the various committees of Parliament were arms of the state, the common thread amongst these disparate promoters of an ethnic question on the census was their simultaneous connection to and autonomy from the state, which allowed greater manoeuvrability in the interpretation of contentious political issues.

The next series of field tests, held between 1985 and 1989, demonstrated that the categories of 'Black British' and 'British Asian' were demanded by respondents but were nevertheless fraught with complexities, since some members of racial minorities born in British colonies overseas considered themselves to be 'British Asian,' though the use of that label was intended to appeal to second-generation Britishborn Asians. When the field trials explicitly tested the reliability of data that allowed everyone to classify themselves as British, the finding was that respondents found the format confusing and the data were compromised. When the question eliminated the qualifier 'British' from the racial category descriptors in subsequent field trials, West Indians continued to express their wish for a Black British category or something similar.

The terms of the test were determined by government officials, with an internal working group created in 1985 to consider the design of the question. Consultations were part of the group's terms of reference, but the stakeholders the working group was to consult throughout the design process were mainly internal, with the sole exception being the CRE, an organisation that was created and funded by the state but was also autonomous from it. The group appears to have understood the necessity of consulting with ethnic minority organisations to prevent the disastrous Haringey results; however, the members were undecided on the crucial question of when to consult. The group recognised that if ethnic minorities were consulted

\footnotetext{
${ }^{36}$ The Sub-Committee was chaired by the Conservative MP John Wheeler and was comprised of one other Conservative MP (John Hunt) and two Labour MPs (Alexander Lyon and Alf Dubs). Interestingly, the members' dedication to their task transcended party lines; Leech (1989) writes that 'the members of this committee were strongly committed to the question' and were often hostile to those who expressed doubts (1989: 10).
} 
before field trials, there was a strong possibility they would object to the designs being tested, but if they were not consulted in advance, 'there might be complaints that we are failing to take heed to the SCORRI [Sub-Committee on Race Relations and Immigration] emphasis on the need for better public relations/publicity'. ${ }^{37}$ There is little evidence that consultations with minority groups took place during the early field trials; according to the OPCS and General Register Office for Scotland $(\mathrm{GRO}(\mathrm{S}))$, the OPCS and CRE began a series of meetings with Community Relations Officers and representatives of ethnic minority organisations in England and Wales in late 1987 when a recommended question had already been decided. The purpose of the meetings was to discuss acceptability and 'to try to find out what doubts or fears, if any, people might have' rather than a deliberative democratic policy-making process ${ }^{38}$ Consultation, in this sense, can be likened to a public relations campaign.

The shift in governmental approaches to racial enumeration from not counting in the name of multiculturalism to counting to justify positive action became clear with the 1998 Census White Paper, which linked the rectification of economic disadvantage in minority populations with the promotion of positive race relations and the general welfare of the public. It also stated that the information collected on housing, employment, educational qualifications and age-structure of each group would help the government carry out its responsibilities under the 1976 Race Relations Act and serve as benchmarks to monitor the implementation of equal opportunities policies (HM Government 1988). The proposed question read: 'Please tick the appropriate box. If the person is descended from more than one group, please tick the one to which the person considers he or she belongs, or tick box 7 and describe the person's ancestry in the space provided.' The categories included (numbered 1-7) were: White; Black; Indian; Pakistani; Bangladeshi; Chinese; Any other ethnic group (and a mark-in space).

At this stage, the government invited further comment from members of the public and from ethnic/racial organisations on whether they would answer the question. Comments from Black groups continued to request more detail on the ethnic origins of Black people in Britain (Sillitoe and White 1992: 155). It was eventually decided, therefore, that the question on the census test of April 1989 should incorporate the following categories (numbered 1-9): White; Black-Caribbean; Black-African; Black-Other (and a mark-in space); Indian; Pakistani; Bangladeshi; Chinese; Any other ethnic group (and a mark-in space). Using this question design, less than one half of one percent of respondents declined to cooperate because of the question and the proportion of Black respondents who objected to the question in the 1989 census test was $19 \%$ - close to the lowest level of objection recorded amongst Black informants since 1979 (White and Pearce 1993: 295).

\footnotetext{
${ }^{37}$ PRO RG 40/397, 1991 Census: Ethnic Question Project Group - terms of reference, 7 January 1985.

${ }^{38}$ OPCS and GRO(S), 'Major steps towards the 1991 Census,' 1981...1991 Census Newsletter, no. 4. 17 December 1987.
} 
The inaugural inclusion of a direct question on ethnicity in the 1991 census was heralded as a resounding success (Coleman and Salt 1996). It also represents a clear break from Britain's previous approach of not counting in the name of multiculturalism to counting, changing to one of counting to justify positive action. The need to comply with the spirit and intent of the Race Relations Act was given as the de facto justification for the collection of racial data. At an international conference in 1992 with representatives from Canadian, American, and British census offices, British civil servants from OPCS noted that ethnic data on the census was collected because of the need for reliable information about unemployment levels, pay equity, housing conditions, and educational attainment of Blacks and Asians in Britain and also 'because of the need to know the extent to which equal opportunity programs are succeeding in reducing the inequalities resulting from discriminatory practices' (White and Pearce 1993: 271). This rationale was also repeated in the White Papers of 1988 and 1999. Note, however, that the legislation itself was consistent through the employment of either approach to racial enumeration. Though census data have clearly been used to provide evidence of racial discrimination and to monitor the effectiveness of government programs (Coombes and Hubbuck 1992; StavoDebauge and Scott 2004; Stavo-Debauge 2005) this argument is far more of a spurious justification after the fact rather than being a singular cause of the racialization in British statistics. Instead, the British case suggests that: (1) unless provisions for ethnic monitoring are expressly stated in legislation, an institutional mandate does not necessarily lead to the implementation of a direct census question on race; and (2) the content of civil rights legislation matters a great deal. If simply the existence of civil rights legislation - or even an acceptance of the legal concept of indirect discrimination - mattered, then Britain would have seen the emergence of an ethnic question far sooner than it did. Civil rights legislation is likely a necessary but insufficient cause for the collection of racial data.

\subsection{Counting in the Name of Multiculturalism: The 2001 Census $^{39}$}

In preparation for the 2001 census the British government sought to institutionalise a consultative process that incorporated input from census data users at an earlier stage in the policy-making process. Though internal working groups comprised of representatives from different departments and levels of government are the norm for many areas of policy making, it was in the mid-1990s that the OPCS decided to 'build on the experience in 1991 by involving users in an active role for planning the 2001 Census' (OPCS and GRO(S) 1995a). This active consultation was to occur through six advisory groups representing the main users of census data. ${ }^{40}$ Members

\footnotetext{
${ }^{39}$ See Appendix 7.2.

${ }^{40}$ These groups represented interests from: (1) the health sector (Health Service Advisory Group);

(2) Local Authorities (Information Development and Liaison Group); (3) academia (Demographic
} 
from each of these groups were represented on the subsequent Working Group on Content, Question Testing and Classification and subgroups were formed to discuss particular questions for consideration on the 2001 census (OPCS and GRO(S) 1995b). The ethnic question, along with other questions concerning income and benefits, language, disability, careers, relationship within household, migration, labour market, qualifications and housing, were identified as high priority for testing (OPCS and GRO(S) 1995c). A subgroup on the ethnicity question was then tasked in April 1995 with determining what changes should be made to the 1991 format, to be presented in a business case to the newly renamed Office for National Statistics (ONS). The core membership of the ethnic question subgroup was comprised of members from all five of the main Advisory Groups, but the working group itself was not large.

Three modifications made to the 1991 census design are of particular interest and speak to Britain's shift from solely counting to justify positive action to also counting in the name of multiculturalism. First, the 2001 census disaggregated the 'white' category and provided the options of 'British,' 'Irish,' and 'Any other White background' with a write-in space. These options stem from the efforts of a surprisingly vocal lobby that persuaded members of the Working Group and ONS to add an Irish category. Unlike the US, lobbies are fairly unusual in the British context - the Westminster system of government and relatively closed policy networks make it far more difficult for interest groups to access decision-makers (Marsh and Rhodes 1992). However, the Irish lobby used the notion of disadvantage to make their case (Aspinall 1996) in multiple institutional access points, targeting both the Working Group and the state and finding a particularly powerful ally in the Department of Health. ${ }^{41}$ This was a necessary step; as one ONS representative noted, lobby pressure from other white ethnic groups, such as the Cypriots, the Greek Cypriots, the Cornish and the Welsh were not persuasive because they could not demonstrate their groups had experienced disadvantages in health, education and the like. ${ }^{42}$ When the Working Group recommended the inclusion of an Irish category on the 2001 census, the ONS has hesitant: 'ONS was reluctant to have it at all...maybe because it wasn't driven by colour. ONS didn't really have a strong appreciation of the nature and scale of the disadvantage. Although evidence was beginning to be published then [...] The Irish group was a tougher sell - it was about 1997 when they came around. There was quite a lot of resistance. ${ }^{43}$ Though the lobby eventually achieved their goal, ONS's unease with counting Irish was partially because the

Liaison Group); (4) central government (Departmental Working Group); (5) the private sector (Business Advisory Group); and (6) devolved territories (Scottish Statistical Liaison Group) (OPCS and GRO(S) 1995a).

${ }^{41}$ Interview with ONS representative, April 2009.

${ }^{42}$ In her words: 'So, in the Irish case, you could argue that there have been discrimination, and if you wanted to overcome that discrimination - one of the key drivers behind this question, that resource allocation needed to be redirected to the improvement of housing or education or health. I don't think the Greek Cypriots could produce such a convincing case that they were suffering discrimination.' Interview with ONS representative, April 2009.

${ }^{43}$ Interview with Working Group member, April 2009. 
category did not align well with the state's conceptualisation of what racial disadvantage is, and therefore, what the ethnic question was designed to measure.

The second major discussion that led to a modification of the 1991 census design concerned the enumeration of mixed-race people. Results from the 1991 census seemed to contradict the assertions espoused by OPCS, that 'people of mixed descent often preferred not to be distinguished as a separate group,' (Sillitoe and White 1992: 149) since approximately one in four members of minority ethnic groups wrote in descriptions in the available free-text fields, and of the 740,000 persons who gave a description nearly one-third, or 240,000 people, wrote in mixed-origins descriptions (Aspinall 2003: 278). These numbers are particularly significant as they outnumbered the population for three groups counted separately on the 1991 census (Chinese, Bangladeshi and Black-African). While some respondents identified with one of the main groups, comparing the count of those mixed-race persons with individuals checking the 'mixed' box in the Labour Force Survey ${ }^{44}$ suggests that around two-thirds of the mixed-race population chose to write in a description rather than select one of the designated categories (Aspinall 2003: 278). The need to find more accurate methods to collect meaningful data on mixed-race people, who were considered a growing population, was generally acknowledged (Bulmer 1996; Owen 1996; Aspinall 2000).

In stark contrast to the United States, there was near unanimous support for the proposal to enumerate mixed-race on the 2001 census from government departments, the CRE, and within the ethnic question subgroup and the Content, Question Testing and Classification Working Group. Aspinall's (1996) report on the ethnic subgroup consultation makes the case for inclusion based on demand from within the group ${ }^{45}$ the increasing size of the group, and the need for analytical clarity, particularly when the data is being used for service provision. The ONS immediately accepted the subgroup's business case and recommendation to count mixedrace. With the substantive question of whether or not to include some provision to classify the multiracial population largely decided, the subgroup discussions focussed on more semantic issues, such as whether the label should read 'mixedrace' when the question itself referred to ethnicity, ${ }^{46}$ the order of labels within the category (i.e., whether the category should read 'White and Black Caribbean' or 'Black Caribbean and White'), the placement of the larger mixed category within the ethnic question, ${ }^{47}$ and the use of the generic label of 'Asian' when the Black

\footnotetext{
${ }^{44}$ Ethnicity data in Great Britain are also available from two other surveys: the Labour Force Survey and the General Household Survey. However, both these surveys are too small to give estimates at a local level, nor is their coverage as encompassing as in the census (Bhrolcháin 1990: 556). It is also interesting to note that the collection of ethnic data was introduced in these surveys in the early 1980s without any public or political debate.

${ }^{45} \mathrm{Of}$ the three arguments, 'demand from within the group' is clearly the weakest. Aspinall's (1996) report relies heavily on evidence from the United States, where multiracial organisations were lobbying the federal government for classificatory changes to the 2000 census. Aspinall notes that the evidence of a similar consciousness or demand in Britain was 'piecemeal'.

${ }^{46}$ Note that the label in the 2001 census simply reads 'Mixed' with no further qualifier.

${ }^{47}$ The category was eventually placed second, after 'White,' to ensure that respondents did not overlook the category (Moss 1999), though some argue that this position is also an effort to avoid the historical stigma of the 'half-caste' (Kosmin 1999).
} 
subgroups were divided into Black-Caribbean and Black-African (Caballero 2004: 121). A multiple response approach to enumerating mixed-race - as is used in both the Canadian and American censuses - was never seriously considered. One ONS representative suggested this was because multi-ticking represented 'a failure of the question' - respondents tick more than one box when they are confused or when instructions are unclear. ${ }^{48} \mathrm{~A}$ member of the ethnicity question subgroup noted that when a two-tier question on ethnic ancestry and ethnic group that required multiticking was tested, 'people were very confused by multi-ticking' ${ }^{49}$ A multipleresponse approach to the mixed-race question, however, was never proposed or tested and it was ultimately the ONS that designed the 2001 mixed-race census categories: White and Black-Caribbean, White and Black-African, White and Asian and a free-text 'any other mixed background.$^{50}$ The inclusion of mixed-race categories in the 2001 census simply was not a contentious issue. This state of affairs is very different from previous policy discussions, which designated the enumeration of multiracial people as a 'problem'. In contrast, the only concerns recorded in this instance were by census users who were apprehensive about the effects on the quality and comparability of the ethnic group data brought about by the inclusion of a mixed-race category.

The third modification is the addition of the headings 'Black or Black British' and 'Asian or Asian British' in the ethnic question. The demand for a 'Black British' category dates back to the early field trials of the 1970s and its continued presence in British census politics over the decades speaks to the discursive connections between race and citizenship. As Ballard (1996) notes, unlike the white majority this population had no objection to a public testament that Britain had become a diverse society, but 'what they did find deeply offensive - understandably enough was any indication that their distinctiveness might be read as an indication that they were in some sense non-British' (Ballard 1996: 12). This sensitivity to the race/citizenship nexus had been used well in the 1984 election, when the Tories, vying to increase their appeal to the Black electorate, released a campaign poster which featured a well-dressed black professional under the words 'Labour says he is black. Tories say he is British,' (Gilroy 1987) implying, of course, that one cannot possibly be both Black and British simultaneously. However, as the 1980s and 1990s wore on, Great Britain experienced a more prominent disconnect between discourses of race relations and immigration than ever before, as second and third generation Blacks and Asians lay claim to being just as British as anyone else. In previous decades, blackness was perceived by the majority population as being synonymous with 'immigrant' (Gilroy 1987: 46; Ballard 1997) but the growth of a politically

\footnotetext{
${ }^{48}$ Interview with ONS representative, 15 April 2009.

${ }^{49}$ Interview with member of ethnic question subgroup, 6 April 2009.

${ }^{50}$ Interviews with members of ethnic question subgroup, 20 April 2009 and 22 April 2009. Note the specific concern with individuals of white/non-white racial backgrounds. According to ONS representatives, the number of non-white mixes (i.e., Black-African and Asian) simply did not warrant specific categories; however, one cannot help but notice the continued lack of consideration of mixes that do not involve the white majority. On this topic, see Mahtani and Moreno (2001).
} 
active generation of British born and bred racial minorities not willing to settle for anything but full citizenship (complete with a sense of belonging as part of the nation) helped to challenge the unspoken, but dominant, paradigm that Britishness was equated with whiteness. ${ }^{51}$

The policy proposal to include the 'Black British' and 'Asian British' as headings rather than categories in the 2001 census came from ONS. Working group members had struggled with the issue of retaining high-quality and comparable data that detailed ancestry while allowing respondents to identify as British, since there was still such demand from the public. On this topic, one working group member commented:

I've got to give credit to the ONS - I couldn't sort out in my head, retaining the data about Black-African or Black-Caribbean ancestry and having Black British as a tick box. Because we knew young people born in Britain, brought up in Britain, identified as Black British, they weren't fussed about ancestry from the Caribbean. Even their parents might have been born in Britain. And, you know, they just felt British. So why not give them a tick box so they can say what they are? And that appealed to a lot of us in the working group...but ONS wanted to know whether in ancestry terms whether people were from the Caribbean or Africa [...] ONS came up with this inspired solution of putting Black British and Asian British in the group label. Ok, you lost the facility to tick Black British as a tick box, but you got reference to national origins. I just thought that was inspired. ${ }^{52}$

The inclusion of some way of recognising Black British or Asian British identities 'had been a sticking point for a long time'. This solution, which acknowledges both race and British nationality and/or citizenship, suggests a symbolic function of the census beyond the task of counting the population. The more intangible elements of census politics, where the census collides with ideas of citizenship and belonging, demand that policy-makers negotiate between technical requirements and the politics of recognition (Taylor 1994).

In sum, these modifications illuminate important changes that had occurred between 1991 and 2001, reflected and reinforced through the census. For example, though it is difficult to measure or define in the social scientific sense, a consistent feature in interviews with government officials and participants in census consultations was the contention that in the late 1980s and early 1990s 'things had changed'. As one interviewee put it:

I think it's a change in society as well. It's a change that's reflected in the change in government. In this government we have now all these protections for different groups; very powerful legislation protecting against discrimination. I think there's much stronger movement to recognise diversity in different societies. There's been a form of identity politics if you like. Britain has been a bit slower than the United States and Canada. I think now there's just so much interest in ethnicity and race in this country; communities are organising themselves a lot more effectively, being involved in consultations and participation and all sorts of government bodies. I think these two things are entrapped with each other. Identity politics and these new legal protections. ${ }^{53}$

\footnotetext{
${ }^{51}$ See Parekh (2000).

${ }^{52}$ Interview with Working Group member, April 2009.

${ }^{53}$ Interview with ethnicity question subgroup member, 6 April 2009.
} 
To be clear, the impetus of enumerating by race in order to meet legislative requirements set out in the Race Relations Act was still an important factor that contributed to the initial and subsequent appearances of the ethnic question. However, as the comment above suggests, there was an equally important acknowledgement and recognition of Britain's diversity that by 2001 occurred both through and within the census.

The ethnic question in the 2001 census exemplifies some tenets of the governmental approach of counting in the name of multiculturalism. The use of this approach is clearly connected to the census designers' efforts to develop a question that would be publicly acceptable and would garner high response rates and high quality data, but there are also symbolic or discursive issues at play in the determination of census categories and classifications. Policy-makers were very concerned with providing options that allowed respondents to identify as what they 'really are' and were willing to adjust census categories (that had previously been successful at attaining high quality data) in order to accommodate these issues of identity and recognition. Also, discourses of race, citizenship and belonging are linked together through the census; the census has become an instrument of diversity governance, used by the state to promote multiculturalism and national diversity as a positive value. This use of the census is particularly potent when combined with the approach of counting to justify positive action, sending signals within the state and to the public-at-large that equality and diversity are important state priorities.

\subsection{Conclusion}

This chapter has detailed the British government's shift in the racialization of statistics, from not counting in the name of multiculturalism in the 1970s and 1980s, to counting to justify positive action in 1991 and also to counting in the name of multiculturalism in 2001. Rather than being driven by singular causes such as social mobilisation, the drive for institutional consistency with civil rights legislation or demography, census categories and classifications are the result of the complicated interplay of ideational and institutional factors.

Institutions clearly matter. The nature of the census is such that there is an institutional imperative to present publicly acceptable questions and policy success is measured by high response rates and the quality of data acquired. Other institutions have mattered in more subtle ways: Britain's unitary system of government and experiments with devolution have allowed local authorities a seat at the policymaking table, while its parliamentary system of government ensures that policy agendas are kept secret and decisions are elite- or bureaucracy-driven. Opportunities for interest groups to access decision-makers are limited and lobby efforts are stymied by party discipline (Marsh and Rhodes 1992; Smith 1993). Social mobilisation in census politics has at times been successful (i.e., the Irish in 2001), at other times has consistently failed (i.e., the Cornish) and has not followed comparative patterns found elsewhere, as demonstrated by the differences between bureaucracy-led decision to enumerate mixed-race in Britain and the lobby-led call for a multiracial 
category in the 2000 US census. However, the state is far from a unitary actor (Hall and Ikenberry 1990); census politics in Great Britain illustrate well that different arms of the state have different interests and policy outcomes are often the result of internal political battles. These conflicting interests of the state are particularly relevant within the census policy network, since the state has a monopoly on setting the rules of the debate and the players permitted at the table. Census data are, first and foremost, a product designed for government use in creating policies and programming (Statistics Canada and United States Bureau of the Census 1993). The state decides what outside groups are consulted; it also decides the timing and purpose of the consultations, which matter a great deal for policy outcomes. Are outside groups consulted before the decision-makers have made up their minds? What is the purpose of consultations with ethnic minority groups: for publicity, to gain approval, to ensure the question is acceptable, or to gather substantive input into the policy-making process? Recall that the timing and intent of consultations were critical to the failure of Haringey; though given the importance of public acceptability it is rather surprising that the government did not consult the racial minorities it intended to enumerate at an earlier stage..$^{54}$

Institutions alone cannot explain the dynamics of census politics in Britain. In fact, historical institutionalism emphasises that policy change is always rather unlikely; policy legacies and path dependent processes reproduce and magnify power distributions in politics, thus limiting opportunities for policy innovation and advantaging the status quo (Pierson 2000). The fact that the British state has sought to improve and amend the ethnic question every decade since its introduction speaks to the more ideational elements involved in the determination of racial categorisations. Ideas about multiculturalism, citizenship and belonging in the British context have played an incredible role in both preventing and supporting the ethnic question. Britain initially experienced a national discomfort with the concept of race. In the late 1970s this anxiety was so great that when minorities requested a category synonymous to 'Black British' the government found the label unacceptable because it placed too much emphasis on differences of race and/or colour. This unease with the concept of race is not an indication of its non-existence, but rather its omnipresence. In Britain, discourses of race and nation are articulated with the same breath, meaning that 'statements about nationality are invariably also statements about

\footnotetext{
${ }^{54}$ The Home Affairs Committee's 1982 Report was particularly scathing, arguing that Haringey was 'a flop' because 'in its form of questions and presentation to the public the Test asked or did everything our inquiry has suggested should not be asked or done, and because in its presentation little was done to provide assurances on confidentiality and the value of questions to ethnic minority groups themselves' (HM Government 1983: vi-vii). The Report condemns the OPCS for the lack of publicity before and during the test, noting that the few public meetings that were held prior to the census rehearsal were poorly attended. It also recommends that OPCS establish an institutionalised consultation process with ethnic minorities based on the model provided by the U.S. Census Bureau's advisory committees, but in its reply the government noted its 'reservations' about setting up such a structure because of the costs involved (HM Government 1984).
} 
"race"' (Gilroy 1987: 57). History dictates that Black and Asian people have been "described, discussed and legislated for on the basis that they were a "problem" for the nation, not an intrinsic part of nor an asset to it. Their presence has been deemed to be temporary and conditional' (Alibhai-Brown 1999: 3). Attempts to promote racial equality have often perceived as threatening to national unity; however, in recent years British identity has sought to incorporate and promote multicultural principles as a source of national pride, though the balance between nationalism, citizenship and race remains somewhat tenuous (Gilroy 1987; Alibhai-Brown 2000; Neal 2003; Small and Solomos 2006; Worley 2005; Pilkington 2008).

The 2011 census demonstrated that Britain remains on its current dual trajectory of counting in the name of multiculturalism and counting to positive action. However, the issues of the nature of race and conceptions of citizenship and belonging are far from settled. They are instead pulled in different directions because of new political developments, such as the UK's membership in the European Union and its implications for immigration controls, Scottish and Welsh devolution, and new paradigms of race relations concerned with the threat of 'home-grown terror' and the integration of Muslim populations. The 2011 UK censuses featured a new question on national identity, which preceded the question on ethnicity. Respondents will be able to choose from six options: English, Welsh, Scottish, Northern Irish, British, or Other with a write-in space. This new question is not a response to the demands for a means of allowing racial minorities to identify themselves without feeling as though such an identification would detract from their sense of belonging in the national community (i.e., Black British or Asian British), but rather is a by-product of processes of devolution in the UK, a growing sense of national identity in Scotland and Wales, the thrust to keep British nationalism intact through policies emphasising 'community cohesion,' and a domestic concern about increasing immigration from Eastern European countries of the EU. Whether this resurgence of nationalism in Britain is a cause or effect of devolution remains to be seen; nevertheless, the consequences for the census are real. It is also worthy of noting that while a multiple response approach was determined to be 'too complicated' to illicit proper responses to the ethnic question, the question on nationality on the 2011 census asked 'How would you describe your national identity?' and instructed respondents to 'tick all that apply' (ONS 2009). Once again, the census proves itself to be a fundamentally political entity situated within broader domestic and international policy debates concerning the nature of race, citizenship and belonging.

Open Access This chapter is distributed under the terms of the Creative Commons Attribution Noncommercial License, which permits any noncommercial use, distribution, and reproduction in any medium, provided the original author(s) and source are credited. 


\section{Appendices}

\section{Appendix 7.1: 1991 Census}

11

\section{Ethnic group}

Please ticilithe appropriate box.

If the person is descended from more than one ethnic or racial group, please tick the group to which the person considers he/she belongs, or tick the 'Any other ethnic group' box and describe the person's ancestry in the space provided.

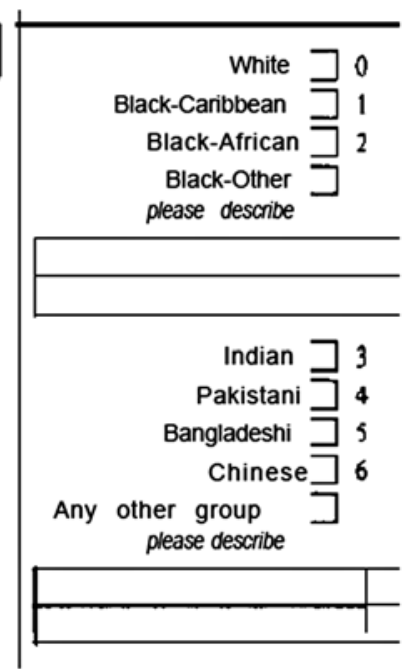




\section{Appendix 7.2: 2001 Census}

8 What is your ethnic group?

- Choose ONE section from A to E, then $\checkmark$ the appropriate box to indicate your cultural background.
A White
$\square$ British
$\square$ Irish

Any other White background, please write in

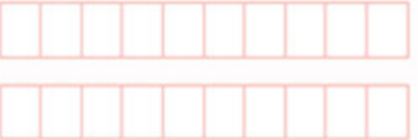

B Mixed

$\square$ White and Black Caribbean

$\square$ White and Black African

$\square$ White and Asian

$\square$ Any other Mixed background, please write in
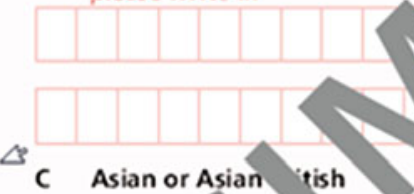

口 Pas

$\square$ Indian

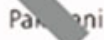

$\square$ Banglac

$\square$ any other Astan background, e write in

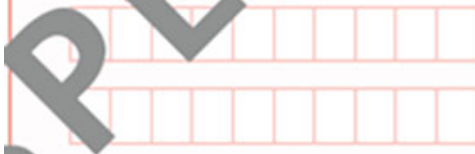

D Black or Black British

Caribbean $\square$ African

$\square$ Any other Black background, please write in

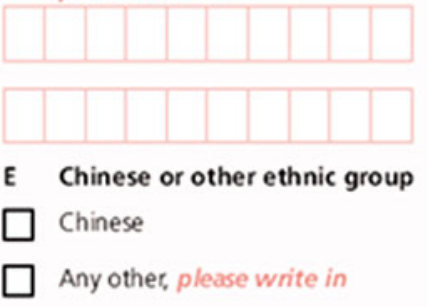




\section{References}

Alibhai-Brown, Y. (1999). True colours: Public attitudes to multiculturalism and the role of the government. London: Institute for Public Policy Research.

Alibhai-Brown, Y. (2000). Who do we think we are? Imagining the New Britain. London: Allen Lane, the Penguin Press.

Anderson, B. (1991). Imagined communities: Reflections on the origins and spread of nationalism (2nd ed.). London/New York: Verso.

Aspinall, P. J. (1996). The development of an ethnic group question for the 2001 census: The findings of a consultation exercise with members of the OPCS 2001 Census Working Subgroup. London: United Medical and Dental Schools.

Aspinall, P. J. (2000). Children of mixed parentage: Data collection needs. Children \& Society, 14, 207-216.

Aspinall, P. J. (2003). The conceptualisation and categorisation of mixed race/ethnicity in Britain and North America: Identity options and the role of the state. International Journal of Intercultural Relations, 27, 269-296.

Ballard, R. (1996). Negotiating race and ethnicity: Exploring the implications of the 1991 census. Patterns of Prejudice, 30(3), 3-33.

Ballard, R. (1997). The construction of a conceptual vision: "Ethnic groups" and the 1991 UK census. Ethnic and Racial Studies, 20(1), 182-194.

Bhrolcháin, M. N. (1990). The ethnicity question for the 1991 census: Background and issues. Ethnic and Racial Studies, 13(4), 542-567.

Bleich, E. (2006). Norms, lesson-drawing, and the introduction of race-conscious measures in the 1976 British Race Relations Act. Policy Studies, 27(3), 219-234.

Brown, J. N. (2009). The racial state of the everyday and the making of ethnic statistics in Britain. Social Text 98, 27(1), 11-36.

Bulmer, M. (1986). A controversial census topic: Race and ethnicity in the British census. Journal of Official Statistics, 2(4), 471-480.

Bulmer, M. (1996). The ethnic group question in the 1991 census of the population. In D. Coleman \& J. Salt (Eds.), Ethnicity in the 1991 census. Volume one: Demographic characteristics of the ethnic minority populations (pp. 33-62). London: HMSO.

Caballero, C. (2004). 'Mixed-race projects': Perceptions, constructions, and implications of mixed-race in the UK and USA. Unpublished dissertation, Bristol: University of Bristol.

Carter, B., Harris, C., \& Joshi, S. (1987). The 1951-1955 conservative government and the racialisation of black immigration. Immigrants and Minorities, 6(3), 335-347.

Coleman, D., \& Salt, J. (1996). The ethnic group question in the 1991 census: A new landmark in British social statistics. In D. Coleman \& J. Salt (Eds.), Ethnicity in the 1991 census. Volume one: Demographic characteristics of the ethnic minority populations (pp. 1-32). London: Office of Population Censuses and Surveys, HMSO.

Commission for Racial Equality, (1980). 1981 census: Why the ethnic question is vital. A discussion document. London: Commission for Racial Equality.

Community Relations Commission. (1975). Review of the race relations act. London: HMSO.

Coombes, M., \& Hubbuck, J. (1992). Monitoring equal employment opportunity at the workplace: The crucial role of the 1991 census. Ethnic and Racial Studies, 15(2), 193-207.

Cornell, S., \& Hartmann, D. (2007). Ethnicity and race: Making identities in a changing world (2nd ed.). Thousand Oaks: Pine Forge Press.

DaCosta, K. M. C. (2007). Making multiracials: State, family and market in the redrawing of the color line. Stanford: Stanford University Press.

Dale, A., \& Holdsworth, C. (1997). Issues in the analysis of ethnicity in the 1991 British census: Evidence from microdata. Ethnic and Racial Studies, 20(1), 160-181.

Foucault, M. (1991). Governmentality. In G. Burchell, C. Gordon, \& P. Miller (Eds.), The Foucault effect: Studies in governmentality (pp. 87-104). Chicago: University of Chicago Press.

Fryer, P. (1984). Staying power: The history of black people in Britain. London: Pluto Press. 
Gilroy, P. (1987). 'There ain't no black in the Union Jack': The cultural politics of race and nation. London: Hutchinson.

Hall, P., \& Ikenberry, J. (1990). The state. Milton Keynes: Open University Press.

Hansen, R. (1999). Citizenship and immigration in post-war Britain: The institutional origins of a multicultural nation. Oxford: Oxford University Press.

Her Majesty's Government. (1984). The government reply to the second report of the home affairs committee session 1982-83 HC 33-I: Ethnic and racial questions on the census. London: HMSO.

Her Majesty's Government. (1988). 1991 census of the population (census white paper) (Cm 430). London: HMSO.

Her Majesty's Government. Parliament. (1983). Second report from the home affairs committee, session 1982-83 HC 33-I: Ethnic and racial questions in the census, volume I: Report together with proceedings of the committee. London: HMSO.

Her Majesty's Government. Select Committee on Race Relations and Immigration. (1975). The organisation of race relations administration. London: HMSO.

Joppke, C. (1999). Immigration and the Nation-State: The United States, Germany and Great Britain. Oxford: Oxford University Press.

Kertzer, D. I., \& Arel, D. (2002). Censuses, identity formation, and the struggle for political power. In D. Kertzer \& D. Arel (Eds.), Census and identity: The politics of race, ethnicity and language in national censuses (pp. 1-42). Cambridge: Cambridge University Press.

Kosmin, B. (1999). Ethnic and religious questions in the 2001 UK census of population policy recommendations (JPR/Policy paper no. 2). http://www.jpr.org.uk/Reports/CS_Reports/PP_ no_2_1999/main.htm

Leech, K. (1989). A question in dispute: The debate about an 'ethnic' question in the census. London: Runnymede Trust.

Mahtani, M., \& Moreno, A. (2001). Same difference: Towards a more unified discourse in "mixed race" theory. In D. Parker \& M. Song (Eds.), Rethinking mixed race (pp. 65-75). London: Pluto Press.

Marsh, D., \& Rhodes, R. A. W. (1992). Policy networks in British politics: A critique of existing approaches. In D. Marsh \& R. A. W. Rhodes (Eds.), Policy networks in British government (pp. 1-26). Oxford: Clarendon.

Miller, J. W. (2007). Reinforcing the divide: The influence of the U.S. census on American identity development. Journal of Human Behavior in the Social Environment, 15(4), 125-141.

Morning, A. (2008). Ethnic classification in global perspective: A cross-national survey of the 2000 census round. Population Research and Policy Review, 27, 239-272.

Moss, C. (1999). Selection of topics and questions for the 2001 census. 97 Population Trends. London: ONS.

Neal, S. (2003). The Scarman report, the Macpherson report and the media: How newspapers respond to race-centred social policy interventions. Journal of Social Policy, 32(1), 55-74.

Nobles, M. (2000). Shades of citizenship: Race and the census in modern politics. Stanford: Stanford University Press.

Nobles, M. (2002). Racial categorization and censuses. In D. Kertzer \& D. Arel (Eds.), Census and identity: The politics of race, ethnicity and language in national censuses (pp. 43-70). Cambridge: Cambridge University Press.

Office for National Statistics. (2009). 2011 census rehearsal, 11 October 2009. Household questionnaire: England.

Office of Population Censuses and Survey. (1975). Country of birth and colour. Population Trends, $2,2-8$.

Office of Population Censuses and Survey. (1980). Tests of an ethnic question, OPCS Monitor CEN 80/2.

Office of Population Censuses and Survey. (1990). Census 1981: General report, England and Wales. London: HMSO.

Office of Population Censuses and Survey. (1996). Looking towards the 2001 Census (Occasional paper 46). London: OPCS. 
Office of Population Censuses and Surveys and General Register Office for Scotland. (1987, December 17). Major steps towards the 1991 Census. 1981...1991 Census Newsletter, no. 4.

Office of Population Censuses and Surveys and General Register Office for Scotland. (1995a, March 3). Coverage in the 1991 Census. Census Newsletter, no. 32.

Office of Population Censuses and Surveys and General Register Office for Scotland. (1995b, June 16). New OPCS area classifications. Census Newsletter, no. 33.

Office of Population Censuses and Surveys and General Register Office for Scotland. (1995c, October 13). OPCS to merge with Central Statistical Office. Census Newsletter, no. 34.

Omi, M., \& Winant, H. (1994). Racial formation in the United States: From the 1960s to the 1990s. New York: Routledge.

Owen, D. (1996). Towards 2001: Ethnic minorities and the census. Coventry: University of Warwick, Centre for Research in Ethnic Relations.

Parekh, B. (2000). Report of the commission on the future of multi-ethnic Britain. London: The Runnymede Trust.

Paul, K. (1997). Whitewashing Britain: Race and citizenship in the post-war era. Ithaca: Cornell University Press.

Pierson, P. (2000). Path dependency, increasing returns, and the study of politics. American Political Science Review, 94(2), 251-267.

Pilkington, A. (2008). From institutional racism to community cohesion: The changing nature of racial discourse in Britain. Sociological Research Online, 13(3). http://www.socresonline.org. uk/13/3/6.html

Potvin, M. (2005). The role of statistics on ethnic origin and "race" in Canadian anti-discrimination policy, UNESCO. Oxford: Blackwell.

Race Relations Board. (1975). Report of the race relations board for 1974. London: HMSO.

Rallu, J.-L., Piché, V., \& Simon, P. (2004). Demography and ethnicity: An ambiguous relationship. In G. Caselli, J. Vallin, \& G. Wunsch (Eds.), Demography: Analysis and synthesis. A treatise in population studies (Vol. 3, pp. 531-549). Amsterdam/Oxford: Elsevier/Academic Press.

Ramdin, R. (1999). Reimagining Britain: Five hundred years of black and Asian history. London: Pluto Press.

Rose, E. J. B., et al. (1969). Colour and citizenship: A report on British race relations. London: Printed for the Institute of Race Relations by Oxford University Press.

Scott, J. C. (1998). Seeing like a state: How certain schemes to improve the human condition have failed. New Haven/London: Yale University Press.

Sillitoe, K. (1978a). Ethnic origins I: An experiment in the use of a direct question about ethnicity, for the census (Office of Population, Censuses and Surveys, Occasional paper no. 8). London: HMSO.

Sillitoe, K. (1978b). Ethnic origins II: An experiment in the use of a direct question about ethnicity, for the census (Office of Population, Censuses and Surveys, Occasional paper no. 9). London: HMSO.

Sillitoe, K. (1978c). Ethnic origins III: An experiment in the use of a direct question about ethnicity, for the census (Office of Population, Censuses and Surveys, Occasional paper no. 10). London: HMSO.

Sillitoe, K., \& White, P. H. (1992). Ethnic group and the British census: The search for a question. Journal of the Royal Statistical Society: Series A (Statistics in Society), 155(1), 141-163.

Simon, P. (2004). Comparative study on the collection of data to measure the extent and impact of discrimination within the United States, Canada, Australia, Great Britain and the Netherlands. Luxembourg: Office for Official Publications of the European Communities.

Small, S., \& Solomos, J. (2006). Race, immigration and politics in Britain: Changing policy agendas and conceptual paradigms 1940s-2000s. International Journal of Comparative Sociology, 47(3-4), 235-257.

Smith, M. J. (1993). Pressure, power and policy: State autonomy and policy networks in Britain and the United States. New York/London: Harvester Wheatsheaf.

Solomos, J. (2003). Race and racism in Britain (3rd ed.). New York: Palgrave Macmillan. 
Spencer, I. R. G. (1997). British immigration policy since 1939: The making of multi-racial Britain. London: Routledge.

Statistics Canada and United States Bureau of the Census. (1993, April 1-3). Challenges of measuring an ethnic world: Science, politics and reality. In Proceedings of the Joint Canada-United States Conference on the Measurement of Ethnicity. Washington, DC: U.S. Government Printing Office.

Stavo-Debauge, J. (2005). Mobilising statistical powers for action against discrimination: The case of the United Kingdom. International Social Science Journal, 183, 43-55.

Stavo-Debauge, J., \& Scott, S. (2004). Comparative study on the collection of data to measure the extent and impact of discrimination in a selection of countries: Final report on England. Lyon: European Commission, Employment and Social Affairs DG.

Taylor, C. (1994). The politics of recognition. In A. Gutmann (Ed.), Multiculturalism: Examining the politics of recognition (pp. 25-73). Princeton: Princeton University Press.

White, P. H., \& Pearce, D. L. (1993, April 1-3). Ethnic group and the British census. In Challenges of measuring an ethnic world: Science, politics and reality. Proceedings of the Joint CanadaUnited States Conference on the Measurement of Ethnicity, pp. 271-306. Washington, DC: U.S. Government Printing Office.

Williams, K. M. (2006). Mark one or more: Civil rights in multiracial America. Ann Arbor: University of Michigan Press.

Worley, C. (2005). "It's not about race. It's about the community": New labour and "community cohesion”. Critical Social Policy, 25(4), 483-496. 